\title{
Cost Benefit Analysis of Different Energy Sources used in Public Secondary Schools in Mtito-Andei Division, Makueni County, Kenya
}

\author{
Kazungu Arnold T*, Kauti Matheaus K and Gikuma-Njuru Peter \\ Department of Environmental Science and Land Resources Management, South Eastern Kenya University, Kenya
}

Submission: April 26, 2019; Published: May 29, 2019

*Corresponding author: Kazungu Arnold T, Department of Environmental Science and Land Resources Management, South Eastern Kenya University, P.O. Box 170-90200, Kitui, Kenya

\begin{abstract}
The purpose of this study was to establish the different energy sources used in public secondary schools in Mtito Andei Division, Makueni County, investigate the factors determining the choice of the energy sources and conduct cost benefit analysis of the major energy sources. The study used Survey Research Design (SRD) and a census survey, with all 30 schools in the division studied. Results revealed that schools use eight (8) different sources of energy; firewood (100\%), electricity (60\%), LPG gas (43\%), batteries (dry cells) (33\%), solar power (27\%), charcoal (23\%), generator $(13 \%)$ and kerosene (13\%). Firewood was the most popular cooking energy source $(100 \%)$ while electricity was the most popular source of energy for lighting (60\%). The three observed energy conservation technologies were energy saving stoves, solar power and energy saving bulbs but had varied adoption $(87 \%, 27 \%$ and $10 \%$ respectively). Adoption of these energy technologies was found to be significantly influenced by school type ( $p$-value $=0.000<0.05$, Pearson $r$ correlation $=0.716)$ and level of education of school head $(p-v a l u e=0.000<0.05$, Pearson $r$ correlation $=0.808$ ). The reasons for the choice of these energy technologies were mainly high cost of other energy sources and need to conserve the environment. Results of the Cost Benefit Analysis (CBA) established that solar power had a Benefit Cost Ratio (BCR) of 1.19 while firewood had a BCR of 0.19 when compared at a discount rate of $13 \%$. The study recommends that national and county governments come up with policies that will make energy conservation technologies affordable and accessible to schools for adoption.
\end{abstract}

Keywords: Energy source; Firewood; Environmental conservation; Cost benefit analysis; Makueni County

\section{Introduction}

Energy plays a vital role in the sustainable development of a society. It affects all aspects of development: social, economic and environmental, including livelihoods, access to water agricultural productivity, health, population levels, education [1] As the UN [1] notes, energy is important in achieving universal primary education since it is required to attract teachers to rural areas and enables studies to continue after dusk in homes and schools.

Globally, in line with the Sustainable Development Goals (SDGs) the UN [2] reported that 1.3 billion people-one in five globally lack access to modern electricity, it further noted that 3 billion people rely on wood, coal, charcoal or animal waste for cooking and heating. The demand for energy has continued to increase as the world population and industrialization continue to increase. For example, global primary energy supply increased by 30 percent between 1990 and 2005 and the worldwide demand is projected to double by 2050 according to the International Energy Agency [3]. The UN [2] reported that 13 billion hectares of forests are being lost every year. Around 1.6 billion people depend on forest for their livelihood. Forests are home to more than $80 \%$ of all terrestrial species of animals, plants and insects. It further noted that due to drought and desertification each year, 12 million hectares are lost (23 hectares per minute).

To address the lack of access to efficient clean energy the United Nation Development Program, called for all nations to put special emphasis on renewable sources of energy [4]. According to World Bank [5], most rural societies experience limited access to modern energy services, due to problems of availability and/or affordability. Recently, the UN [2] reported that renewable energy currently constitutes $15 \%$ of the global energy mix. This report points out that the uptake of renewable energy technologies is still low globally.

The UN [2] in one of its SDGs on education noted that enrolment in primary education in developing countries had reached 91\%. This increase suggests a corresponding increase 
in enrolment in secondary schools which is likely to increase energy demand in schools. Currently, public schools in Kenya are experiencing an exponential increase in student enrolment which put more pressure on energy needs. This can be attributed to the government of Kenya's commitment to the provision of quality basic education for all through the introduction of Free Primary Education (FPE) in 2003 and Free Day Secondary Education (FDSE) in 2008 to enhance retention of learners in schools. The launch of FDSE in 2008 lead to an increased enrolment in public secondary schools [6]. This has resulted in increased demand for energy.

Schools use different types of energy such as firewood, charcoal, electricity, LPG-gas, solar power and kerosene to meet their energy needs, however most schools dominate in the use of biomass for cooking [7]. A study by Renewable Energy Technology Assistant Programme [8] reported that 75\% of the 4,215 secondary schools in Kenya, which were boarding type, depended entirely on fuelwood for their daily cooking and water heating purposes whereby a typically boarding school consumed between 200-300 tonnes of fuelwood annually. A similar study by Kituyi in 2000 [9] revealed that 90 percent of 20,000 schools in Kenya relied entirely on fuelwood for daily cooking and heating purposes. This indicate that schools spend a lot of money on energy bills, and schools in Mtito Andei Division, Makueni County are not exempted, therefore, it is expected that they spend a lot of money every year on energy, which may have a profound impact on the schools' financial resources and to the environment. Moreover, cooks in school where wood biomass is the main energy source may be at high risk of suffering from health problems due to smoke as a result of continued burning of wood biomass. Exposure to Indoor Air Pollution (IAP) from the combustion of biomass and fossil fuels are the causal agent of several diseases such as; Acute Respiratory Infections (ARI), lung cancer, asthma, tuberculosis, low birth weight and diseases of the eye [10]. The UN [2] noted that the greenhouse gas emissions from human activities are driving climate change and continue to rise. Carbon dioxide concentrations have increased by $40 \%$ since pre-industrial times, primarily from fossil fuel emissions and secondarily from net land use change emissions. An efficient and cost-effective energy system to schools is central to reducing the huge amount of money spent on energy, improve health status of the cooks and to conserve the environment. There is, therefore, need to understand the current status of energy sources used by schools in Mtito-Andei Division and do cost benefit analysis in order to identify the most suitable for use in institutions.

Previous studies have shown that modern, cleaner and affordable energy options can help create a more child-friendly environment that encourages school attendance and reduces the significant dropout rates experienced in many low-income countries [11]. For, example, studies have provided evidence that electricity can facilitate access to educational media and communication in schools and in homes and it can increase use of distance-learning modules. Access to electricity provides the opportunity to use more sophisticated equipment for teaching such as projectors, computers, printers, photocopiers, and science equipment, which allows wider access to morespecialized teaching materials and courses [11].

In their study, Sovacool et al. [12] noted that in Mali, electrification has increased levels of girls' school attendance, improved performance, and drastically improved boy to girl ratios. Electrified schools and villages have been documented to have lower drop-out rates, higher test scores, and higher proportions of girls entering secondary education. Anup et al. [13] documented that in Nepal, girl student enrolment increased by 23.3 percent across a sample of villages that had received electricity at schools. In Kenya, lighting has enabled teachers to provide extra teaching early in the day and late at night to make up for material not adequately covered during normal hours [14].

Student population influences the choice of energy in schools. For instance, the study by RETAP [8] found that the demand of fuelwood by schools is likely to continue increasing in Kenya because of the increase in the number of schools yearly due to population growth hence increased deforestation rates.

There have been numerous studies to investigate environmental degradation attributed to biomass energy production and consumption. These studies show that biomass production has impact on hydrology, soils, wildlife and species habitat. Its use over time has contributed to forest degradation, soil erosion, desertification, loss of biodiversity due to preference to wood types and adverse health effects as a result of indoor air pollution [15-17].

Energy consumption levels and the types of energy used depends on a variety of factors but mainly on availability and cost of energy resources [18]. Also, among the poor, biomass resources are used in unsustainable and inefficient ways due to lack of access to information, financial resources and technology [19].

Many existing studies in the broader literature have shown that adopting cleaner cooking methods will improve health and reduce illness-related expenditures, stimulate development and contribute to environmental sustainability (World health organization [10]. A major constraint to the adoption of costeffective energy technologies is that the initial capital outlay for these technologies tends to be high [20,21]. Studies by Lay et al. [22] reveals that income plays an important role in switching to transitional and more modern energy sources. The social cost brought by use of biomass is enormous. For instance, Ezzati \& Kammen [23] contends that exposure to indoor air pollution (IAP) from the combustion of traditional fuels in Kenya enhances the risk of acute respiratory infection.

Modern cost effective and clean energy sources such as biogas offers various benefits such as saving fuel wood and 
protecting forests as well as reduces expenditure on fuels. In addition, it reduces the time spent on cooking and improves hygienic conditions [24].

Philips Lebel (2000) in one of his papers which examines the economic efficiency of alternative renewable energy technologies in Botswana emphasized that valuation of future versus present costs and benefits must be taken into accounts when one is making useful comparisons of whether a given technology is economical. Cost-Benefit Analysis (CBA) has been advanced as a technique for systematically estimating the efficiency impacts on policies [25]. Cost-benefit analysis (CBA) compares costs and benefits, both of which are quantified in common pecuniary units [26].

Most schools use wood biomass for cooking [7]. This reveals that schools spend a lot of resources on energy, and it is expected that this has a profound impact on the schools' financial resources and to the environment. An efficient and cost-effective energy system to schools' is central to reducing the huge amount of money spent on energy and to conserve the environment. This study aimed to address these issues by conducting cost benefit analysis (CBA) of the energy sources used in schools in Mtito Andei Division in order to identify the most appropriate energy sources for use in institutions. In this paper, the CBA was conducted in order to provide the basis for determination of the criteria to be used to determine if an investment was economical. Specifically, in this paper the benefit cost ratio (BCR) criterion was used to measure the viability of the energy source investment decision. By applying CBA, the respondents were provided with information on decision making on the choice of energy sources as well as on environmental conservation in case of use of biomass.

\section{Methodology}

\section{The study area}

The study area lies in Makueni County (Figure 1) which covers an area of $8,034.7 \mathrm{Km} 2$. The County borders Kajiado to the West, Taita Taveta to the South, Kitui to the East and Machakos to the North. It lies between latitude $1^{\circ} 35^{\prime}$ and $30^{\circ} 00^{\prime}$ South and between longitude $37^{\circ} 10^{\prime}$ and 38 $30^{\prime}$ East. The County lies in the arid and semi-arid zones of the southeastern region of the country. Its terrain is generally low-lying from $600 \mathrm{~m}$ above sea level in Tsavo at the southern end of the County [27]. The County is currently divided into nine Sub-counties and twenty-five Divisions. Specifically, the study was carried out in Mtito Andei Division which lies in Kibwezi East Sub-county and it borders Tsavo East National Park to the West and Tsavo West National Park to the South. Mtito-Andei Division is the largest amongst the three Divisions in Kibwezi Sub-County with 30 public secondary schools and 76 primary schools [28].

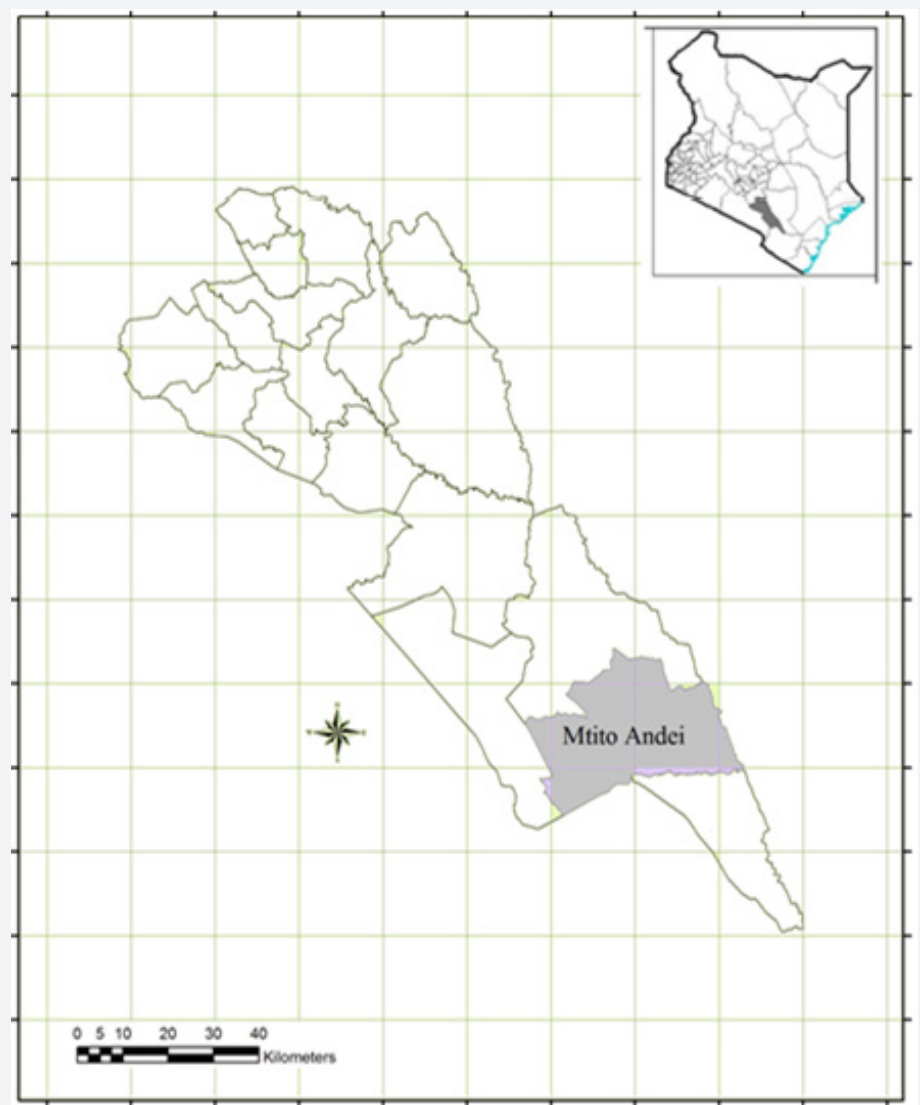

Figure 1: Map showing Makueni County, its location in Kenya (inset) Mtito Andei, the study area. 
The choice of the study area was influenced by several factors;

a) It neighbours Chyulu Hills which is one of the eighteen national government gazetted water towers [29] and is characterized by indiscriminate clearance of indigenous trees and shrubs which are used by locals for firewood and charcoal burning; b) It is in a dryland and Semi-Arid region where firewood is a scarce resource; and

c) The area is faced with major challenges in accessing alternative sources of energy due to high levels of poverty [30], which limits acquisition, leading to dependence on trees and shrubs by learning institutions for firewood. As a result, the area is bound to suffer a great deal of environmental degradation and loss of biodiversity.

\section{Research Design}

Table 1: Public secondary schools in Mtito Andei Division by zone, category and student enrolment.

\begin{tabular}{|c|c|c|c|}
\hline Zone & School & Category & Student Enrolment \\
\hline \multirow{7}{*}{ Mtito-Andei } & 1. Joanna Chase & Boys boarding & 280 \\
\hline & 2. Miangeni & Mixed day and boarding & 179 \\
\hline & 3. Nzoila & Mixed day & 92 \\
\hline & 4. Mbeetwani & Mixed day & 78 \\
\hline & 5. Mavindini & Mixed day and boarding & 182 \\
\hline & 6. Kyusiani & Mixed day and boarding & 85 \\
\hline & 7. Kathekani & Mixed day and boarding & 240 \\
\hline \multirow{10}{*}{ Kambu } & 8. St. Mary’s Komboyo & Girls boarding & 246 \\
\hline & 9. Iiani & Boys day and boarding & 316 \\
\hline & 10. Muthingiini & Boys boarding & 287 \\
\hline & 11. Darajani & Boys day and boarding & 389 \\
\hline & 12. Kamulalani & Mixed day and boarding & 247 \\
\hline & 13. St. Lucy Kilimani & Mixed day & 72 \\
\hline & 14. Silanga & Mixed day & 168 \\
\hline & 15. Komboyo Mixed & Mixed day & 181 \\
\hline & 16. Molemuni Girls & Girls boarding & 270 \\
\hline & 17. Canaan & Mixed day & 120 \\
\hline \multirow{7}{*}{ Nthongoni } & 18. Mwitasyano & Mixed day & 210 \\
\hline & 19. Kithing'iisyo & Mixed day and boarding & 326 \\
\hline & 20. Kiuani & Mixed day and boarding & 310 \\
\hline & 21. Kasue girls & Girls boarding & 425 \\
\hline & 22. Matulani & Mixed day and boarding & 308 \\
\hline & 23. Ivingoni & Mixed day and boarding & 210 \\
\hline & 24. Tsavo West & Mixed day & 91 \\
\hline \multirow{6}{*}{ Ngwata } & 25. Ititi & Mixed day and boarding & 165 \\
\hline & 26. Kiteng'ei & Mixed day & 213 \\
\hline & 27. Yumbuni & Mixed day and boarding & 190 \\
\hline & 28. Misuuni & Mixed day and boarding & 344 \\
\hline & 29. Yikitaa & Mixed day and boarding & 135 \\
\hline & 30. Ngwata & Mixed day and boarding & 333 \\
\hline Total & & & 6692 \\
\hline
\end{tabular}

Source: Kibwezi Sub-County education office.

The study used Survey Research Design (SRD) and a census survey, where all 30 public secondary schools in the study area were interviewed (Table 1). Purposive sampling was used to identify respondents to be interviewed at the schools.
They included the school principal, bursar(s) and $\operatorname{cook}(\mathrm{s})$. The principal was interviewed to provide data on background information of the school, energy needs and sources, determinants for the choice of energy source, expenditure on 
energy as well as the benefits associated with different energy sources. The school bursar was interviewed in gathering data on energy expenditure over the years. The school $\operatorname{cook}(\mathrm{s})$ provided useful general information on the benefits and challenges of the various energy sources; these include problems of smoke and suitability of the energy sources. The study used multiple methods of data collection such as field surveys, observations and interviews to gather information.

For the purposes of this research analysis, CBA was conducted by using the Benefit-cost ratio (BCR) decision rule. BCR decision rule was employed in order to adequately present the required information for the basis of solid decision making. Greater difficulties are always encountered in the actual measurements of costs and benefits as well as selection of an appropriate discount rate [31]. A benefit to cost ratio of over one indicates that benefits probably exceed costs and that the investment is promising. A ratio under one indicates that benefits are probably less than costs and that the project sponsor should consider further study or innovative strategies to justify the project [32].

For this study, the analysis assumes a 1-year (2017) benefit horizon starting after project (solar power and energy saving stoves) installation in 2016. These types of projects in schools typically provide a stream of benefits that last for many years. The timeframe for analysis of the benefits and costs must therefore extend well into the future to measure project benefits accurately [32]. However, for this study the analysis did not extend into the future since the focus was to determine the energy source that can save the environment by lessening pressure on natural forests rather than the economically aspects of the energy source and also due to difficulties in selection of an appropriate discount rate for such projects in schools.

Equations 1 through 3 illustrate the concept of discounting in CBA as adapted from the works of Philips Lebel [33] in the Financial and Economic Analysis of Selected Renewable Energy Technologies in Botswana. To determine a cumulative Present Value of Benefits (PVB) that are payable in annual instalments over a period of one year is given as:

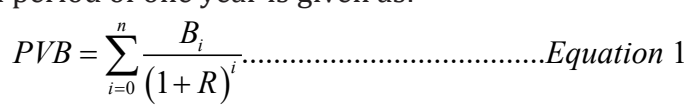

Where $B$ is the economic value of benefits in each time period, $R$ is the discount rate, $i$ is the initial time period and $n$ represents the present value period of time to be considered.

It must be noted that the initial time period is not always discounted, though it appears in the formula. This is so because the exponential of 0 carries the value of 1 . The result of using the above discount rate illustrates that by using a discounted value for each benefit for each period of time, one has an accurate way of aggregating the benefits that are expected in the future time period with the present time benefits [31].
The following equation is used to determine the cumulative present value of costs (PVC) when conducting BCR.

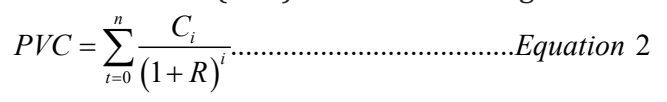

Where $\mathrm{R}$ depicts the same discount rate in equation $2, \mathrm{C}$ is the economic value of costs in each time period, Ci represents the cost in the ith time period and, $n$ again represents the present value period of time to be considered.

Since Equations 1 and 2 are determined, they provide the basis for the determination of the three criteria often used to determine if an investment is economical. They are Net Present Value (NPV), Benefit-Cost Ratio (BCR) and Internal Rate of Return (IRR) [31]. In the case of this study the BCR criterion is used to measure if an investment decision is viable. The benefitcost ratio is the ratio of present benefits to present costs, which is derived from equations 1 and 2, defined as:

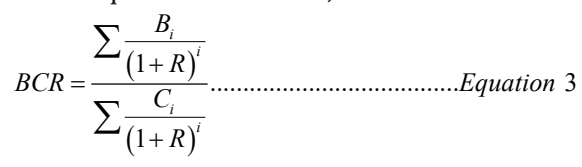

In order to conduct the CBA, the researchers relied on the benefits and costs information from the respondents. To be most effective in the analysis, this data was supplemented with information that described the type of benefit and cost in their respective context. This also facilitated the grouping of costs and benefits. The types of costs considered for analysis included: initial capital investment, cost of maintenance and operating cost/energy bills, while the types of benefits included: savings from energy bills, savings from regular maintenance cost, savings from paying health bills, reduced indoor air pollution. Those costs and benefit which could not be monetized were excluded (not valued) during the analysis in this study. After calculating the total monetary value of benefits and costs, the final step of the analysis was to compare the cost and benefit of the energy source/technology in a benefit-cost ratio. Cost benefit analysis (CBA) was calculated using Equation 3 above [33], where BCR is the benefit cost ratio for the energy source under consideration, $\mathrm{Bi}$ is the economic value of benefits in each time period, $\mathrm{R}$ is the discount rate, $\mathrm{i}$ is the initial time period, $\mathrm{Ci}$ is the economic value of costs in each time period. By applying this formula, the BCR for solar power and firewood were generated.

The first benefit -cost analysis compares the solar power benefits with the costs in order to establish whether it is a worthwhile investment. The second benefit-cost analysis compares the firewood benefits with costs in order to ascertain if it is a worthy investment. These two energy sources (solar power and firewood) were selected for CBA analysis as they are shown in the study to be the major energy sources in use, they may have positive or negative effect to the environment and data on benefits and cost measure was available which facilitated the benefit -cost analysis. 


\section{Results and Discussion}

\section{Types of energy sources used in public schools in mtito andei division}

Public secondary schools in the study area use eight (8) different sources of energy to meet daily energy needs (Table 2). Firewood was the most popular source of energy (100\%), followed by electricity (60\%), LPG gas (43\%), batteries (dry cells) (33\%), solar power (27\%), charcoal $(23 \%)$, generator $(13 \%)$ and kerosene $(13 \%)$. This collaborate with the study by Moronge \& Maina [7] whose findings show that firewood, electricity, diesel, liquefied petroleum gas (LPG), kerosene and charcoal were the main sources of energy for cooking, lighting and laboratories in boarding schools in Thika Sub-County, Kenya.

Table 2: Types of energy sources used in schools in the study area $(\mathrm{N}=30)$.

\begin{tabular}{|c|c|c|}
\hline Energy Source & Frequency & Percent \\
\hline Firewood & 30 & 60 \\
\hline Electricity & 18 & 43.3 \\
\hline LPG gas & 13 & 33.3 \\
\hline Batteries (dry cells) & 10 & 26.7 \\
\hline Solar power & 8 & 23.3 \\
\hline Charcoal & 7 & 13.3 \\
\hline Generator & 4 & 13.3 \\
\hline Kerosene & 4 & \\
\hline
\end{tabular}

Studies by GOK [34] and Ifejika et al. [35] in Makueni County, found that firewood and charcoal use accounted for $84.8 \%$ and $11.1 \%$ respectively in secondary schools. These findings agree with the current study which found that all (30) public secondary schools in the study site use firewood (Table 3), which is a clear indication of possible serious impact on forests resources in the Table 3: Five commonly used energy sources for cooking in school $(\mathrm{N}=30)$.

\begin{tabular}{|c|c|c|c|}
\hline Type of Use & Energy Source & Frequency & Percent \\
\hline \multirow{3}{*}{ Cooking } & Firewood & 30 & 100 \\
\cline { 2 - 4 } & Charcoal & 3 & 23.3 \\
\cline { 2 - 4 } & LPG gas & 2 & 10 \\
\cline { 2 - 4 } & Kerosene & 1 & 3.7 \\
\hline
\end{tabular}

The five commonly used energy sources used for cooking in the schools were firewood, charcoal, LPG-gas, kerosene and electricity used by $100 \%, 23 \%, 10 \%, 7 \%$ and $3 \%$ of schools respectively. The over relaince on firewood for cooking can be attributed to lack of alternative energy sources for cooking in schools. It was found that most schools in the study area had been using firewood for cooking since their establishment.

\section{Determinants for choice of the energy source}

Table 4: Main reason/preference for using the energy source in school $(\mathrm{N}=30)$.

\begin{tabular}{|c|c|c|c|}
\hline Main Reason for use & $\begin{array}{c}\text { Energy } \\
\text { Source }\end{array}$ & Frequency & Percent \\
\hline $\begin{array}{c}\text { Highly suitable for cooking } \\
\text { compared to other energy } \\
\text { sources }\end{array}$ & Firewood & 30 & 100 \\
\hline Less expensive & Charcoal & 7 & 23.3 \\
\hline Efficient and affordable & LPG gas & 3 & 10 \\
\hline Alternative and faster to use & Kerosene & 2 & 6.7 \\
\hline Easy and faster to use & Electricity & 1 & 3.3 \\
\hline
\end{tabular}

area. The study observed that no school in the study area was using biogas as a source of energy. This can be attributed to the prohibitive high cost of construction that hinders adoption of the technology [36]. Biogas plants have a high construction cost [37] which can be prohibitive for many institutions.
Table 4 presents the main determinants for choice of the energy source. Analysis of results indicated that firewood was mostly prefered at $100 \%$ as it was percieved to be highly suitable for cooking compared to other sources of energy, charcoal at $23 \%$ was less expensive. This concurs with findings by Tee et al. [38] who established that the preference by the population to use fuel wood was due to familiarity with working with the fuels, cost and affordability. Studies have shown that the loss of tree cover leads to soil erosion, has serious impact on the hydrological cycle especially on pollution of water bodies due to siltation which diminishes the quality and quantity of waters available for use [16,39].

\section{Forms of modern energy technologies adopted by Schools in Mtito Andei Division}

The study established that the selected schools had employed the use of modern energy efficient technologies which would help in conserving the environment and in reduction of energy bills by limiting energy usage in particular. These included solar power, energy saving stoves and energy saving bulbs, with 
respectively $27 \%, 87 \%$, and $10 \%$ of schools using them (Table 5).

Table 5: Percentage of schools using Energy saving technologies in Mtito Andei Division ( $\mathrm{N}=30)$.

\begin{tabular}{|c|c|c|}
\hline Energy Technology & Frequency & Percent \\
\hline Energy saving stoves & 26 & 86.7 \\
\hline Solar power & 8 & 26.7 \\
\hline Energy saving bulbs & 3 & 10 \\
\hline
\end{tabular}

\section{Factors influencing adoption of energy technology}

For the purposes of this study, the term adoption of energy technology referred to the choice of the school to accept, acquire and use a new energy innovation/technology that was available in the market in order to reduce energy bills and to save the environment. The term school type in this study referred to whether a secondary school was Boys boarding, Girls' boarding, day school or mixed day and boarding.

A test of correlation between the school type and adoption of energy showed that school type significantly influenced the adoption of energytechnology by the school ( $p$-value $=0.000<0.05$, Pearson $r$ correlation $=0.716$ ) It was found that boarding schools were more adoptive to energy technologies compared to day schools due to the number of times cooking was done in such schools as well as the high need to provide lighting to the students during the night hence the need to cut down energy costs. However, RETAP [8] reported that $75 \%$ of boarding type secondary schools in Kenya, depended entirely on fuelwood for their daily cooking and water heating purposes.

Correlation analysis showed that level of education of school head significantly influenced the adoption of energy technology ( $p$-value $=0.000<0.05$, Pearson $r$ correlation $=0.808$ ). This implied that the more educated a school head was the more likely they would embrace modern energy technology compared to the less educated. This can be attributed to the fact that at higher levels of education school heads are more exposed to environmental issues through various informative forums, conferences and relevant sources. The results are in consonance with findings of Karanja [40] who established that without education, respondents may not appreciate the importance of technological devices in reducing over-dependence on scarce energy resources. Highly educated people have higher energy saving behaviour and opt for more efficient energy sources [41].

\section{Cost benefit analysis}

A summary of components of cost benefit analysis for firewood and solar energy sources is presented in Table 6. This cost benefit analysis compares the costs and benefits of solar power and firewood energy sources for the same period of time (2017). The valuation of the costs and benefits was based on the market price using the prevailing market price in the study site as well as the financial data from the schools.

Table 6: Details of Cost benefit analysis for firewood and solar energy sources in Mtito Andei secondary schools.

\begin{tabular}{|c|c|c|}
\hline Energy Type & Element & Monetary Value (Kshs) \\
\hline \multirow{12}{*}{ Firewood } & Present Value of Costs at 13\% Discount Rate & \\
\hline & (i) Cost of installation of energy saving stoves & $4,296,000$ \\
\hline & (ii) Cost of buying firewood from vendors & $3,168,000$ \\
\hline & (iii) Cost of loss of tree cover & Not valued \\
\hline & (iv) Annual cost of repairing energy saving stoves & 384,000 \\
\hline & (v) Cost of repainting sooty kitchen per year & 300,000 \\
\hline & (vi) Cost of health bills for the school cook & Not valued \\
\hline & Total costs & $8,148,000$ \\
\hline & Present Value of Benefits at 13\% Discount Rate & \\
\hline & (i) Reduced expenditure on buying firewood by $50 \%$ after installation of energy saving stoves & $1,584,000$ \\
\hline & (ii) Reduced indoor air pollution & Not valued \\
\hline & Total benefits & $1,584,000$ \\
\hline \multirow{11}{*}{ Solar Power } & Present Value of Costs at 13\% Discount Rate & \\
\hline & (i) Cost of installation of solar panels & $5,160,000$ \\
\hline & (ii) Cost of maintenance & 351,000 \\
\hline & Total cost & $5,511,000$ \\
\hline & Present Value of Benefits at 13\% Discount Rate & \\
\hline & (i) Avoided cost of buying firewood & $3,168,000$ \\
\hline & (ii) Avoided loss of tree cover & Not valued \\
\hline & (iii) Avoided cost of repainting the kitchen walls & 300,000 \\
\hline & (iv) Avoided cost of repairing energy saving stoves & 384,000 \\
\hline & (v) Savings from electricity bill & $2,754,700$ \\
\hline & Total benefits & $6,606,700$ \\
\hline
\end{tabular}


The study established that Kenya shillings (Kshs) $8,148,000$ was the total present value of costs of firewood and Kshs.1,584,000 was the cumulative present value of benefits of firewood at a discount rate of $13 \%$. It was observed that Kshs.5,511,000 was the total present value of costs of solar power and Kshs.6,606,700 was the total present value of benefits of solar power at a discount rate of $13 \%$.

Further analysis aimed at comparison of benefit-cost ratios (Table 7) for solar power and firewood was conducted. The Analysis revealed that solar power had a benefit-cost ratio (BCR) of 1.19 implying that the solar benefits exceeded the costs when compared at a discount rate of $13 \%$. The BCR of firewood was 0.19 , which indicated that the costs of firewood exceed the benefits when compared at a discount rate of $13 \%$. Results of the analysis concurred with IEA [42] which reported that the capital costs for many renewable energy technologies (RETs) had reduced considerably and were further expected to decrease over the decade that followed. It can therefore be concluded that by adopting solar energy technology, schools would save as well as contribute greatly in conserving the environment due to reduced demand for firewood. Several opportunities exist in the solar energy technology for rural and education institutions applications including solar photovoltaic water pumping systems, solar chick brooding, solar refrigeration, solar drying, solar water purification, solar air and water heating among others [43]. However, as alluded by Karekezi \& Kithyoma [44], the renewable energy resource potential in Africa has not been fully exploited, mainly due to the limited policy interest and investment levels. In addition, technical and financial barriers have contributed to the low levels of uptake of (RETs) in the region.

Table 7: Comparison of Benefit-Cost Ratios for solar power and firewood.

\begin{tabular}{|c|c|c|}
\hline \multirow{2}{*}{} & \multicolumn{2}{|c|}{ Energy Type } \\
\cline { 2 - 3 } & Solar Power & Firewood \\
\hline $\begin{array}{c}\text { Benefit-cost } \\
\text { comparison }\end{array}$ & $\frac{6,606,700}{5,511,000}$ & $\frac{1,584,000}{8,148,000}$ \\
\hline Benefit-cost Ratio & 1.19 & 0.19 \\
\hline
\end{tabular}

The findings showed that schools use eight different energy sources including firewood, charcoal, electricity, solar power, LPG-gas, generator and batteries. Overall, it was found that firewood was the most popular energy source in the study area. Moronge \& Maina [7] found that firewood and charcoal were the main sources of energy for cooking in boarding schools in Thika Sub-County, Kenya. Kituyi [9] revealed that 90 percent of 20,000 schools in Kenya relied entirely on fuelwood for daily cooking and heating purposes. The study noted that various reasons existed for the choice of energy sources. The most prevalent reasons for choice of energy sources included; suitability of the energy source for cooking and cost of energy sources. The types of energy used depends on a variety of factors but mainly on availability and cost of energy resources [18]. A study done in Nigeria by Adepoju et al. [45] concludes that availability, affordability and convenience of usage are critical issues to be taken into consideration when making choices among available energy sources.

Factors that influenced the choice for modern energy technology included; the school type and education level of school head. The study revealed that the forms of modern energy technologies adopted by the respondents included energy saving stoves, solar power and energy saving bulbs. Adepoju et al. [45] observed that respondents without formal education had higher likelihood of using fuel wood and charcoal as major sources of energy compared to their highly educated counterparts. A comparison of the benefit-cost analyses for solar power and firewood revealed that solar power had a BCR greater than one at 1.19 while firewood had a BCR less than one at 0.19 . Modern energy sources such as solar power offers various benefits such as saving fuel wood, protecting forests, reducing expenditure on fuels, reducing the time spent on cooking and improving hygienic conditions [24]. Moreover, Murphy [46] contend that by adopting the modern energy sources women and children will have more time for education. On the other hand, the continued use of biomass especially firewood is said to be one of the main causes of loss of biodiversity and wide scale deforestation in Kenya [16].

\section{Conclusion and Recommendation}

The study concluded that over-reliance on firewood for cooking in schools had strained the already diminishing supply from natural forests and further exacerbated desertification, loss of biodiversity and land degradation in the study area. Further, it can be concluded that solar power benefits exceeded the costs and the BCR of solar power was greater than one, then solar power appears to be a good investment to schools. Benefit cost analysis had been used to compare the benefits and costs of the energy sources. The study recommended that national and county governments come up with policies that will make these energy technologies affordable and accessible to schools for adoption.

\section{Acknowledgement}

The authors acknowledge South Eastern Kenya University (SEKU) Management for support and time accorded to the staff to conduct field work and prepare the article. The authors would like to thank Mr. Musyoki Mutua. the field assistant, for his dedication and cooperation, Mr. Daudi Mutunga for his input in data analysis and Dr P. Kariuki for providing the study area map. Finally, we would like to appreciate the cooperation accorded by the respondents, who willingly and gladly provided information during field data collection.

\section{References}

1. UN (United Nations) (2010) Energy for sustainable development. New York. 
2. UN (United Nations) (2015) Sustainable Development Goals Fact sheet. 2015 Time for Global Action for people and planet.

3. IEA (International Energy Agency) (2007) Renewables in Global Energy Supply; an IEA Fact Sheet. Paris, France.

4. UNDP (United Nations Development Program) (1997) Energy after Rio: Prospects and Challenges.

5. World Bank (1996) Meeting the Challenge for Rural Energy and Development. Washington DC: World Bank, USA.

6. Republic of Kenya (2005) Sessional Papers No. 1 of 2005 and No. 14 of 2012 .

7. Moronge J, Maina MN (2015) Energy use and conservation in boarding schools in Thika Sub-County, Kenya. International Journal of Education Research 3(9): 1-12.

8. Renewable Energy Technology Assistant Programme (RETAP) (2007) Sustainable cooking energy solutions for schools in Kenya.

9. Kituyi E (2000) Atmospheric Trace Gas Emission for Domestic Biomass Burning in Kenya. Published PhD thesis, University of Nairobi, Kenya.

10. WHO (World Health Organization) (2003) Climate change and human health: risks and responses? Summary.

11. Mapako M (2010) Energy, the Millennium Development Goals and the Key Emerging Issues. Department of Environmental Affairs, South Africa.

12. Sovacool, BK, Clarke S, Johnson K, Crafton M, Eidsness J, et al. (2013) The Energy-Enterprise Gender Nexus: Lessons from the Multifunctional Platform (MFP) in Mali. Renewable Energy 50: 115-125.

13. Gurung A, Gurung OP, Sang EO (2011) The potential of a renewable energy technology for rural electrification in Nepal: A case study from Tangting. Renewable Energy 36(11): 3203-3210.

14. Charles Kirubi, Arne Jacobson, Daniel Kammen, Andrew Mills (2009) Community-Based Electric Micro-Grids Can Contribute to Rura Development: Evidence from Kenya. World Development 37(7): 1208 1221.

15. Bruce N, Perez-Padilla R, Albalak R (2000) Indoor air pollution in developing countries: a major environmental and public health challenge. Bull World Health Organ 78(9): 1078-1092.

16. Mugo, Gathui (2010) Biomass energy use in Kenya. A background paper prepared for the International Institute for Environment and Development (IIED) for an international workshop on biomass energy, 19-21 October 2010, Parliament House Hotel, Edinburgh. Practical Action, Nairobi, Kenya.

17. IRF (InfoResources Focus) (2006) Sustainable energy and rural poverty alleviation. Information resources focus no2/06. Zollikofen.

18. Karekezi S, Kithyoma W (2002) Renewable energy strategies for rural Africa: is PV led renewable energy strategy the right approach for providing modern energy to the rural poor of Sub-Saharan Africa? Energy Policy 30(11-12): 1071-1086.

19. Kammen DM, Ezzati M (2001) Evaluating the health benefits of transitions in household energy technologies in Kenya. Energy Policy 30(10): 815-826

20. Bazart C (2003) Liberalization of Energy Markets and Company Strategies: A Diagnosis on the European Gas Market. Spring Meeting of Young Economists in Belgium, April, Louven.

21. Ilie L, Horobet A, Popescu C (2007) Liberalization and regulation in the EU energy market. MPRA paper 6419. University of Munich.

22. Lay J, Ondraczek J, Stoever J (2013) Renewables in the Energy Transition: Evidence on Solar Home Systems and Lighting Fuel Choices in Kenya. Energy Economics 40: 350-359.
23. Ezzati M, Kammen DM (2002) Quantifying the effects of exposure to indoor air pollution from biomass combustion on acute respiratory infections in developing countries. Environ Health Perspect 109(5): 481-488.

24. Gregory R (2006-2012) China-Biogas, Eco-Tippings Points project.

25. Weimer DL, Vining AR (1992) Policy Analysis Concepts and Practice. $\left(2^{\text {nd }}\right.$ edn), Prentice Hall, New Jersey.

26. Yogesh S, Kuldeep KS (2013) Energy-cost analysis of alternative sources. International Journal of Engineering Research and Applications (IJERA) 3(1): 803-810.

27. Kenya National Bureau of Statistics (2010) The 2009 Kenya Population and Housing Census: Counting our People for the implementation of Vision 2030. Vol 1A, Nairobi, Kenya. Government printer.

28. Kibwezi Sub-County Education Office (2017) D.E.O's office Kibwezi Sub-County.

29. GoK (Government of Kenya) (2012) Kenya Water Towers Agency Order 2012 CAP 445 (State Corporation Act), Government Printer, Nairobi.

30. Makueni County Annual Development Plan (MCADP) (2016).

31. Ogunlade AA (2008) Comparative cost-benefit analysis of renewable energy resources for rural community development in Nigeria. Master's dissertation, North-West university.

32. Jack F (2015) Tiger Benefit Cost Analysis: 22 Fillmore Transit Priority Project. Maryland.

33. Lebel P (2000) Financial and Economic Analysis of Selected Renewable Energy Technologies in Botswana. New Jersey: Centre for Economic Research on Africa.

34. GoK (Government of Kenya) (2013) Makueni First County Integrated Development Plan 2013-2017. pp. 2-36.

35. Ifejika SC, Kiteme B, Wisemann U (2007) Droughts and Famine, The underlying Factors and Causal Links among Agro-Pastoral Households in Semi-Arid Makueni District, Kenya. Global Environment Change 18(1): 220-223

36. Mwakaje, AG (2012) Dairy Farming and the Stagnated Biogas use in Rungwe District, Tanzania: An investigation of the constraining factors. Institute of resource Assessment, Unversity of Daresalam.

37. Bond T, Templeton MR (2011) History and future of domestic biogas plants in the developing world. Energy for Sustainable Development 15(4): 347-354.

38. Tee, Ancha Pu, Asue (2009) Evaluation of fuel wood consumption and implications on the environment: Case study of Makurdi area in Benue state, Nigeria. Department of Social and Environmental Forestry, University of Agriculture Makurdi.

39. IEA (International Energy Agency) (2006) World Energy Outlook. Paris: Organization for Economic Cooperation and Development.

40. Karanja L (1999) Adoption of Energy Conserving Technologies by Rural Households in Kathiani Division, Machakos District. Master's Thesis, Kenyatta University.

41. Njenga M, Karanja N, Prain G, Malii G, Munyao P, et al. (2009) Community-based energy Briquette production from urban organic waste at Kahawa Soweto Informal Settlement, Nairobi. International Potato Center (CIP), Peru.

42. IEA (International Energy Agency) (2002) Renewable Energy: Into the Mainstream. Netherlands: IEA.

43. Iloeje OC (2004) Status of Renewable Energy in Nigeria. Abuja: Energetic Solutions.

44. Karekezi S, Kithyoma W (2003) Renewable Energy in Africa: Prospects and Limits. Renewable Energy Development. The Workshop for African 
Energy Experts on Operationalizing the NEPAD Energy Initiative, Operationalizing the NEPAD Energy Initiative. Novotel, Dakar, Senegal.

45. Adepoju OA, Oyekale AS, Aromolaran O (2012) Factors influencing domestic energy choices of rural households in Ogun State, Nigeria. J Agric Soc Sci 8: 129-134.
46. Murphy JT (2001) Making the energy transition in rural East Africa: "Is leapfrogging an alternative?" Technological Forecasting and Social Change, No. 68.

\section{Your next submission with Juniper Publishers} will reach you the below assets

- Quality Editorial service

- Swift Peer Review

- Reprints availability

- E-prints Service

- Manuscript Podcast for convenient understanding

- Global attainment for your research

- Manuscript accessibility in different formats

( Pdf, E-pub, Full Text, Audio)

- Unceasing customer service

Track the below URL for one-step submission https://juniperpublishers.com/online-submission.php 